\title{
Cosmopraxis: Relational methods for a pluriversal IR
}

\author{
Amaya Querejazu* \\ University of Antioquia, Medellín, Antioquia, Colombia and Aberystwyth University, Wales, United Kingdom \\ ${ }^{\star}$ Corresponding author. Email: Amaya.querejazu@udea.edu.co
}

(Received 5 October 2020; revised 4 May 2021; accepted 28 June 2021; first published online 23 August 2021)

\begin{abstract}
Bringing ontological questions back into IR has been key to opening discussions about plurality and difference in terms of the coexistence of related and plural worlds and realities, for example through notions such as relationality and pluriversality. The problem is that in trying to develop relational approaches as an alternative to the 'Western/modern' - atomistic - ontology, relationality, relations, and their meanings can become fixed, translating them into 'things'. The article maintains that cosmopraxis - as a complex pluriversal, multidimensional set of experiences - not only illustrates how relations relate without fixing their meaning, but also provides us with relevant insights to contribute to think of a pluriversal and more plural IR.
\end{abstract}

Keywords: Relationality; Pluriverse; Relational Methods; Cosmopraxis; Worlding

\section{Introduction}

Coexistence is never easy, and nothing is more political than claims about existence. Bringing ontological questions back into IR has been key to opening new discussions about plurality and difference in terms of the coexistence of different worlds and realities. One aspect that has come under increased challenge is the dominant assumption that we inhabit a single one-world world or universe ${ }^{1}$ that makes it possible to think of a 'global IR'. ${ }^{2}$ David Blaney and Arlene B. Tickner have argued that the global IR project is problematic because it assumes that difference can coexist within a single 'multiplex' world, when in fact diverse cosmologies or worlds are converted into contending perspectives on a shared world order. ${ }^{3}$ It is through similar colonising processes that the logic of Western $/$ modern $^{4}$ atomistic ontology has become dominant and

\footnotetext{
${ }^{1}$ John Law, 'What's wrong with a one-world', Heterogeneities (2011), pp. 1-14.

${ }^{2}$ Amitav Acharya and Barry Buzan, Non-Western International Relations Theory: Perspectives on and beyond Asia (London, UK and New York, NY: Routledge, 2010).

${ }^{3}$ David Blaney and Arlene B. Tickner, 'Worlding, ontological politics', Millennium, 45:6 (2017), pp. $293-311$.

${ }^{4}$ Western modernity is itself not a fixed concept. Critical literature like the 'Decolonial Turn' uses the concept as if it were homogeneous. See Edgardo Lander et al. (eds), La colonialidad del saber: Eurocentrismo y ciencias sociales. Perspectivas Latinoamericanas (Buenos Aires: CLACSO, 2005); Walter D. Mignolo, Historias locales diseños globales: Colonialidad, conocimientos subalternos y pensamiento fronterizo (Madrid: Akal, 2003); Chengxin Pan, 'Toward a new relational ontology in global politics: China's rise as holographic transition', International Relations of the Asia-Pacific, 18:3 (2018), pp. 339-67. Harding has illustrated the existence of different Western modernities: Sandra Harding, Sciences from Below: Feminisms, Postcolonialities, and Modernities, Science and Technology (Durham, NC and London, UK: Duke, 2008); Berman, its dual characteristics: Marshall Berman, All That is Solid Melts into Air: The Experience of Modernity (London, UK: Penguin, 1988); and see also Dussel on the existence of modernities in 'non-Western' geographies: Enrique Dussel, 1492 : El encubrimiento del Otro. Hacia el origen del 'mito de la Modernidad' (La Paz: Plural Editores, 1994). To avoid repeating the essentialisation of a Western modernity, here I use the term atomistic ontologies to highlight the ontological features.

(c) The Author(s), 2021. Published by Cambridge University Press on behalf of the British International Studies Association. This is an Open Access article, distributed under the terms of the Creative Commons Attribution licence (http://creativecommons.org/licenses/by/4.0/), which permits unrestricted re-use, distribution, and reproduction in any medium, provided the original work is properly cited.
} 
universalised, effacing other realities or worlds. ${ }^{5}$ Drawn from Newtonian cosmology ${ }^{6}$ that conceives of reality as primarily constituted by atoms (units), atomistic ontologies refer to a type of rationality founded on the premise that entities are singular 'essences ${ }^{\text {"7 }}$ that exist on their own as separate, present, and definable.

The result is a logic of binary separation and opposition of those units that constitute the fundamental order of reality, ${ }^{8}$ based on what Bruno Latour called the 'great divides'. ${ }^{9}$ Such logic has permeated almost every realm of scientific and academic work, also becoming the dominant rationality to approach reality and its 'objects of study'. IR does not escape from these assumptions; in fact, one of its fundamental roots is the acceptance of what L. H. M. Ling calls the Westphalian world, constituted mainly by states/units ${ }^{10}$ and, the idea that we live in a single world. ${ }^{11}$ This restricts other possible ways of reflecting upon plural existence, and limits political imaginations on how to address planetary problems.

Relational ontologies, according to which 'the primary ontological units are not "things" but phenomena, dynamic topological reconfigurings/entanglements/relationalities/(re)articulations of the world', ${ }^{12}$ enable and provide us with analytical tools and methods to think of existence as pluriversal. ${ }^{13}$

This article further contributes to what has been called the 'relational turn in IR', but moves beyond more traditional relational approaches such as Patrick Thaddeus Jackson and Daniel H. Nexon 'relations before states' or 'relationalism', ${ }^{14}$ and is more committed to a deep conception of ontological relationality, which according to David Blaney and Tamara A. Trownsell

\footnotetext{
${ }^{5}$ Blaney and Tickner, 'Worlding, ontological politics and the possibility of a decolonial IR'.

${ }^{6}$ See Milja Kurki, International Relations in a Relational Universe (Oxford, UK: Oxford University Press, 2020).

${ }^{7}$ Arturo Escobar, 'Latin America at a crossroads: Alternative modernizations, post-liberalism, or post-development?', Cultural Studies, 24:1 (2010), pp. 1-65.

${ }^{8}$ Richard Howitt and Sandra Suchet-Pearson, 'Ontological pluralism in contested cultural landscapes', in Kay Anderson, Mona Domosh, Steve Pile, and Nigel Thrift (eds), Handbook of Cultural Geography (London, UK: Sage Publications Inc., 2002), pp. 557-71; Philippe Descola, 'Más allá de la Naturaleza y de la Cultura', Cultura y naturaleza: Aproximaciones a propósito del bicentenario de la independencia de Colombia (Bogotá: Jardín Botánico, 1996); Bruce Mazlish, Reflections on the Modern and the Global (New Brunswick, Canada and London, UK: Transaction Publishers, 2014).

${ }^{9}$ Bruno Latour, We Have Never Been Modern (Cambridge, MA: Harvard University Press, 1993).

${ }^{10}$ L. H. M. Ling, The Dao of World Politics: Towards a Post-Westphalian, Worldist International Relations (New York, NY: Routledge Chapman \& Hall, 2013); Yaqing Qin, 'A relational theory of world politics', International Studies Review, 18:1 (2016), pp. 33-47.

${ }^{11}$ Tamara A. Trownsell, Arlene B. Tickner, Amaya Querejazu, Jarrad Reddekop, Giorgio Shani,Kosuke Shimizu, Navnita Chadha Behera, and Anahita Arian, 'Differing about difference: Relational IR from around the world', International Studies Perspectives (2020), pp. 1-40; Kurki, International Relations in a Relational Universe; Chengxin Pan, 'Toward a new relational ontology in global politics: China's rise as holographic transition', International Relations of the Asia-Pacific, 18:3 (2018), pp. 339-67.

${ }^{12}$ Karen Barad, Meeting the Universe Halfway: Quantum Physics and the Entanglement of Matter and Meaning (Durham, NC: Duke University Press, 2007), p. 141.

${ }^{13}$ These relational approaches are evident in Emilian Kavalski, 'The guanxi of relational international affairs', Chinese Political Science Review, 3:3 (2018), pp. 233-51; Emilian Kavalski, 'Normative power Europe and normative power China compared', Korean Political Science Review, 51:6 (2017), pp. 147-70; Pan, Toward a New Relational Ontology in Global Politics; John M. Hobson and Alina Sajed, 'Navigating beyond the Eurofetishist frontier of critical IR theory: Exploring the complex landscapes of non-Western agency', International Studies Review, 19:4 (2017), pp. 547-72; Qin, 'A relational theory of world politics'; Ling, The Dao of World Politics; Giorgio Shani, 'Human security as ontological security: A postcolonial approach', Postcolonial Studies, 20:3 (2017), pp. 275-93; Shilliam, The Black Pacific; Tamara A. Trownsell, Amaya Querejazu, Giorgio Shani, Navnita Behera, Jarrad Reddekop, and Arlene B. Tickner, 'Recrafting International Relations through relationality', E-International Relations (2019), pp. 1-10; Kurki, International Relations in a Relational Universe.

${ }^{14}$ Patrick Thaddeus Jackson and Daniel H. Nexon, 'Relations before states: Substance, process and the study of world politics', European Journal of International Relations, 5:3 (1999), pp. 291-332; Patrick Thaddeus Jackson and Daniel H. Nexon, 'Reclaiming the social: Relationalism in anglophone international studies', Cambridge Review of International Affairs, $32: 5$ (2019), pp. 582-600. The 'relational turn' is still circumscribed to the mainstream literature in IR, because it leaves the ontological nature of agents and structures as 'things' 'out there' unscathed. Consequently, it does not resolve the problem of ontological difference.
} 
begins by assuming interconnection as prior to the existence of entities. Entities don't exist but by entanglements with others, ${ }^{15}$ contesting the idea of the existence of independent units and separation. As part of what Milja Kurki describes as a new generation of relational thought 'less committed to "fixing" what a relational perspective entails, in favour of encouraging manifold situated relational knowledges and conversations between different forms of relational thought and practice', ${ }^{16}$ this article can be approached as an attempt 'to think truly relationally, that is, without "things" or "backgrounds", from relations ${ }^{\text {'17 }}$ or 'deep relationality". ${ }^{18}$ If relations are everything and everywhere, what exists is not only the result of relations relating but it becomes evident that humans and their worlds are not isolated from their environments but deeply interconnected to one another and to the other-than-human worlds (natural, animal, and spiritual). Consequently, some relational approaches use the notion of the pluriverse to address those interconnections of worlds within the cosmos.

Here, I refer to the cosmos as a complex plural ethos of interconnections; the times/spaces realm of dimensions (human, natural, spiritual, physical) in which societies organise their lives according to basic assumptions about reality and their beliefs on how these realities come to be (cosmologies). ${ }^{19}$ Accordingly, the cosmos can unfold in a universe or a pluriverse, and in fact both coexist. ${ }^{20}$ This approach, as Kurki argues, ${ }^{21}$ helps to bridge the distinction between natural or scientific and social or anthropological approaches to the cosmos. Pluriversal relationalities are concerned with the coexistence of all those cosmologies and their interaction, ${ }^{22}$ opening space for political negotiations that allow other realities to exist on their own terms. ${ }^{23}$ Doing this allows to think of global politics not in terms of difference contained in one 'universal' and global framework (one-world world), but in a plurality of worlds coexisting (pluriversal politics), or pluriverse. This contributes to make IR more responsive to pluriversal or relational communities around the world, or as Blaney and Trownsell argue, to recraft IR by worlding multiply. ${ }^{24}$

While it has been proposed that 'relationality' can change the rules of the game and foster a plural IR, confronting mainstream assumptions deeply seeded in atomistic ontologies is far from easy. In fact, it takes considerable effort to challenge powerful narratives and representations of reality, and this creates another problem. In highlighting the alternatives, some approaches based on relational ontology ${ }^{25}$ focus so much on trying to define and characterise relationality - as an antidote to 'Western/modern' atomistic ontology - that they fall into what appears to be an inevitable trap: defining relationality in ways that reifies relations and transforms them into 'things'.

In this article, I argue that a possible way out of this dilemma is to focus on the how of relations relating instead of what relationality is. By relations relating I mean the constant and ongoing interaction of co-constitutive and transformative processes that create realities. From a relational standpoint, this expression avoids substantialism or defines relations and reality as

\footnotetext{
${ }^{15}$ David Blaney and Tamara Trownsell, 'Recrafting IR by worlding multiply', Uluslararas Iliskiler (Special Issue on Globalizing IR) (forthcoming).

${ }^{16}$ Milja Kurki, 'Relational revolution and relationality in IR: New conversations', Review of International Studies (2021), pp. $1-16$ (p.1).

${ }^{17}$ Ibid., p. 2.

${ }^{18}$ Shilliam, The Black Pacific; Trownsell et al., 'Differing about difference'.

${ }^{19}$ See Kurki, International Relations in a Relational Universe.

${ }^{20}$ Newtonian physics and Western/modern atomistic cosmologies and quantum physics and relational cosmologies. See Kurki, International Relations in a Relational Universe; Keiichi Omura, Grant Jun Otsuki, Shiho Satsuka, and Atsuro Morita (eds), The World Multiple (London, UK: Routledge, 2019).

${ }^{21}$ Kurki, International Relations in a Relational Universe.

${ }^{22}$ Trownsell et al., 'Recrafting International Relations through relationality'.

${ }^{23}$ Kimberly Hutchings, 'Decolonizing global ethics: Thinking with the pluriverse', Ethics and International Affairs, 33:2 (2019), pp. 115-25.

${ }^{24}$ Blaney and Trownsell, 'Recrafting IR by worlding multiply'.

${ }^{25}$ See, for example, Pan, Toward a New Relational Ontology in Global Politics; Ling, The Dao of World Politics.
} 
'things'. As the constant action of connecting, it refers to the vital force that constitutes existence. Descriptively it refers to what relationality does, or the how of relationality. Cosmopraxis illustrates the how of relations relating as being in relation/being relation. After all, how we think and act in the world is tied up with our cosmological visions of the universe and our understandings of our role in it. How we understand time and space, and the relationship between humans, and between humans and other-than-humans is central to expanding our imagination and seeing the role of politics and the 'participants' in the political pluriversal dialogue. ${ }^{26}$ In highlighting the political implications of such a project, Donna Haraway has stated that it matters what worlds world worlds. It matters what stories tell stories'; ${ }^{27}$ here I propose that it matters how worlds world worlds, and how stories are told. The notion of cosmopraxis is used to illustrate another way of approaching 'relationality' that avoids fixing its meaning by using some relational ways or relating that can inform our understanding of a pluriversal IR. It should be clear that this is not an article about methodology involving a series of procedures. Rather, I argue that by focusing on relations, relating the ways of doing things/connectors/relations that are discussed in subsequent pages, forms part of a relational practice that also affects and transforms realities. Cosmopraxis is thus about worlding, performing, and relating, using daily lived practices (or relational ways) that connect us to the cosmos.

The article is structured as follows. The first section illustrates the setbacks of reifying relationality by briefly exploring some examples. In the second part I explore the notion of cosmopraxis, the complex practice or worlding that not only helps to overcome the problem of reifying relationality but also shows its pluriversal dimension. The third part refers to the role of relational ways or means of relating and how they can be used, experienced, and lived to explain how cosmopraxis is enacted; the fourth mentions some contributions of cosmopraxis for thinking and experiencing pluriversal IR.

\section{'Reifying' relationality?}

Research that draws from relational ontologies has provided the field of IR conceptual, theoretical, and empirical tools for approaching the coexistence of difference while at the same time unsettling naturalised assumptions about categories that we usually use as 'objects of study', such as the state, the human, the environment, and political agency, just to mention a few. Relational arguments question the primary assumption of separation. For instance, the 'great divide' between nature and society ${ }^{28}$ has led to conceptions of the human as isolated and independent from the other-than-human realms (matter, nature, spiritual), and deeply affected the ways we imagine and study 'the global' by establishing specific orders, logics, and rules that only make that separation more profound. By contesting this assumption and arguing that everything is related, relational ontologies have been used to argue in favor of expanding our approaches to the cosmological realm and of considering different cosmologies as part of the political 'imagination'. ${ }^{29}$

\footnotetext{
${ }^{26}$ Kurki, International Relations in a Relational Universe, p. 3.

${ }^{27}$ Donna Haraway, Staying with the Trouble: Making Kin in the Chthulucene (Durham, NC and London, UK: Duke University Press, 2016), p. 35.

${ }^{28}$ Emilian Kavalski and Magdalena Zolkos, 'The recognition of nature in international relations', in Patrick Hayden and Kate Shick (eds), Recognition and Global Politics: Critical Encounters Between State and World (Manchester, UK: Manchester University Press, 2016), pp. 139-55; Bruno Latour, 'Another way to compose the common world', HAU: Journal of Ethnographic Theory, 4:1 (2014), pp. 301-07.

${ }^{29}$ Kurki, International Relations in a Relational Universe; Anna M. Agathangelou and L. H. M. Ling, 'The house of IR: From family power politics to the poisies of worldism', International Studies Review, 6:4 (2004), pp. 21-50; Ling, The Dao of World Politics; Qin, 'A relational theory of world politics'; L. H. M. Ling and A. H. M. Nordin, 'On relations and relationality: A conversation with friends', Cambridge Review of International Affairs, 32:5 (2019), pp. 654-68; Giorgio Shani, 'Toward a post-Western IR: The "Umma", "Khalsa Panth", and critical International Relations theory', International Studies Review, 10:4 (2008), pp. 722-34; Noah Theriault, Timothy Leduc, Audra Mitchell, June Mary Rubis, and Norma Jacobs Gaehowako, 'Living protocols: Remaking worlds in the face of extinction', Social and Cultural Geography (2019),
} 
Such thinking has made possible the development of other insightful ways to talk about political agency involving other-than-human beings as political actors. ${ }^{30}$ Expanding relational frameworks fosters other types of dialogues based on ontological difference and the bridges (relations) among them by addressing difference not as a problem but as a necessary ingredient of existence. ${ }^{31}$ Other analyses have focused on how to consider identity from relational perspectives. ${ }^{32}$ Additionally, this body of literature has also revealed and highlighted the importance of other forms of knowing ${ }^{33}$ and the need for other methodologies to better understand and reflect on them, ${ }^{34}$ thus contributing to further decolonise IR. ${ }^{35}$

The problem is that conceptualising relations as a way to 'fit them' into academic conversations can lead scholars to translate their being into 'relationality', a fixed meaning, reifying relations as 'things' or essences. ${ }^{36}$ As we will see, regardless of their powerful relational reasoning, such arguments cannot seem to escape the very categories they try to unsettle, such as state, identity, culture, ${ }^{37}$ and talk about relational-ity as something 'complete' and 'out there'. Concerns with trying to define and produce concepts and knowable 'objects', and establish certainties also condition what is expected from scholars: to provide clear, apprehensible answers, to respond to research programmes and agendas, and to elaborate further theorisation from such concepts. In that context, arguments to open up spaces to relational worlds in academic languages can

pp. 1-16; Zoe Todd, 'An indigenous feminist's take on the ontological turn: "Ontology" is just another word for colonialism', Journal of Historical Sociology, 29:1 (2016), pp. 4-22.

${ }^{30}$ Hobson and Sajed, Navigating beyond the Eurofetishist Frontier of Critical IR Theory; Stephen Hobden and Emilian Kavalski (eds), Posthuman Dialogues in International Relations (London, UK and New York, NY: Routledge, 2018); Audra Mitchell, 'Only human? A worldly approach to security', Security Dialogue, 45:1 (2014); Juanita Sundberg, 'Decolonizing posthumanist geographies', Cultural Geographies, 21:1 (2014), pp. 33-47; Robbie Shilliam, 'Race and revolution at Bwa Kayiman', Millennium: Journal of International Studies, 45:3 (2017), pp. 269-92.

${ }^{31}$ Amaya Querejazu, 'Why relational encounters?', in Trownsell et al., 'Differing about difference', pp. 7-10; Kavalski, 'The guanxi of relational international affairs'; Trownsell et al., 'Recrafting International Relations through relationality'.

${ }^{32}$ Silvia Rivera Cusicanqui, Sociología de la imagen: Miradas ch'ixi desde la historia andina (Buenos Aires: Tinta Limón, 2015); Marisol De la Cadena, 'Indigenous cosmopolitics in the Andes: Conceptual reflections beyond "politics", Cultural Anthropology, 25:2 (2010), pp. 334-70.

${ }^{33}$ Theriault et al., 'Living protocols'; Vanessa Watts, 'Indigenous place-thought \& agency amongst humans and nonhumans (First Woman and Sky Woman go on a European world tour!)', Decolonization: Indigeneity, Education \& Society, 2:1 (2013), pp. 20-34; Bawaka Country, Sandie Suchet-Pearson, Sarah Wright, Kate Lloyd, Matalena Tofa, Laklak Burarrwanga, Ritjilili Ganambarr, Merrkiyawuy Ganambarr-Stubbs, Banbapuy Ganambarr, and Djawundil Maymuru, 'Bunbum ga dhä-yutagum: To make it right again, to remake', Social and Cultural Geography (2019), pp. 1-17.

${ }^{34}$ To mention some examples of relational methodologies such as 'learning from below' (Robbie Shilliam, The Black Pacific); 'sentipensar' or feeling/knowing (Arturo Escobar, Sentipensar con la tierra: Nuevas lecturas sobre el desarrollo, territorio y diferencia (Medellín: Ediciones Unaula, 2014)); Arturo Escobar, Pluriversal Politics (Durham, NC and London, UK: Duke University Press, 2020); 'creative listening' (L. H. M. Ling and Carolina Pinheiro, Dialogics in Multiple Worlds: 'Creative Listening' for the UA/West (2013); Arlene B. Tickner and Amaya Querejazu, 'Weaving worlds: Cosmopraxis as relational sensibility', International Studies Review (2021), pp. 1-18.

${ }^{35}$ Although it should be noted that not all decolonising projects are relational or base their arguments on deep relations, it could be argued that all relational approaches aim at unsettling naturalised ontological assumptions, making strong arguments for decolonising or questioning mainstream approaches. Examples of postcolonial yet not relational approaches are the decolonial turn (Lander et al. (eds), La colonialidad del saber; Mignolo, Historias locales diseños globales) or other postcolonial approaches (Sandro Mezzadra, Gayatri Chakravorty Spivak, Chandra Talpade Mohanty, Ella Shohat, Stuart Hall, Dipesh Chakrabarty, Achille Mbembe, Robert J. C. Young, Nirmal Puwar, and Federico Rahol, Estudios postcoloniales: Ensayos fundamentales (Madrid: Traficantes de sueños, 2008); Dipesh Chakrabarty, Provincializing Europe: Postcolinial Thought and History of Difference (Princeton, NJ: Princeton University Press, 2000); Himadeep Muppidi, The Politics of the Global (Minneapolis, MN and London, UK: University of Minnesota Press, 2004).

${ }^{36}$ Here I use the term reify to refer to the process of making something rather abstract a concrete, separable thing (re comes from Latin 'thing').

${ }^{37}$ Ling, The Dao of World Politics; Yaqing Qin and Astrid H. M. Nordin, 'Relationality and rationality in Confucian and Western traditions of thought', Cambridge Review of International Affairs, 32:5 (2019), pp. 601-14; Karen Tucker, 'Unraveling coloniality in international relations: Knowledge, relationality, and strategies for engagement', International Political Sociology, 12:3 (2018), pp. 215-32. 
fall into what Trownsell ${ }^{38}$ calls a 'slippery slope' of relational worlds being translated back into things. Unwillingly or unconsciously, relationality becomes yet another 'object of study' to give insights to IR research ${ }^{39}$ and is commonly portrayed as the opposite of 'Western/modern' atomistic ontologies, reproducing a familiar binary logic. The alternatives that relational approaches offer are interrupted by the lack of more relational languages and methods. This is problematic because any -ism or -ity (relationism ${ }^{40}$ or relationality) is the expression of verbs (action/doing) or adjectives (qualities) transformed into time lasting concepts with relative fixed meaning, privileging the presence of being ('relationality') over the process of becoming ('relations relating'). ${ }^{41}$

To illustrate my point, what follows are examples of the 'slippery slope'. Karen Tucker defines relationality as 'a research sensibility that emphasizes connection and inter-relatedness among individuals, communities, histories, and knowledges, as well as the worlds - both past and present - in which these are rooted'. ${ }^{42}$ The risk here in seeing relationality as a sensibility for research, is that of suppressing the ontological nature of relations and their cosmic scope. The relational worlds of these communities as cosmical more-than- human ethos gets lost. For Pan 'a relational ontology focuses on things in relationality'. ${ }^{43}$ In this instance, a certain fixing of relations also takes place: Pan does not contest the existence of units, such as states and wholes such as the global economy, leading him to use relationality as relations between things. Even Anna M. Agathangelou and L. M. H. Ling's arguably critical contribution, ${ }^{44}$ does not completely escape this trap. In their effort to develop methods to engage difference, they too use the same units and categories that reify relations, including state and society. And according to Yaqing Qin, 'The fluid and moving relations provide the dynamics of this cosmos, therefore, there is no need for exterior forces to empower it. ${ }^{35}$ While Qin makes very compelling arguments about relations, he also has to translate them into the 'the primary unit of analysis', ${ }^{46}$ keeping atomistic thinking unchallenged.

For Robbie Shilliam, relationality is 'a deep, global infrastructure of anticolonial connectivity' ${ }^{47}$ Relationality is a strong decolonial tool, but relationality is not only the state of being of the colonised. As complex processes of interconnectedness, relations are neutral (not good or bad). Indeed, Kozuke Shimizu ${ }^{48}$ has argued that relationality has also been used for imperialist purposes. This also illustrates the problem of trying to approach relationality by means of what it is.

Another challenge is using non-relational methods to illustrate relational ontologies, such as Ling's ${ }^{49}$ use of dialectic method to show how Daosim contributes to dialogue in IR. ${ }^{50}$ Dialectics is based on the confrontation of opposite poles produces a synthesis, a hybrid that is also fixed. ${ }^{51}$ Dialectics might not be the ideal method because it itself is based on the assumption of existence of separate units that interplay in terms of versus and the interaction produces another separate unit. Therefore, applying dialectics to relations of opposites and complementation in duality like the yin and yang, maintains and reproduces dichotomies. For example, from

\footnotetext{
${ }^{38}$ Tamara A. Trownsell in Trownsell et al., 'Differing about difference', p. 33.

${ }^{39} \mathrm{Pan}$, 'Toward a new relational ontology in global politics'.

${ }^{40}$ Jackson and Nexon, 'Relations before states'.

${ }^{41}$ Kurki, International Relations in a Relational Universe.

${ }^{42}$ Tucker, 'Unraveling coloniality in international relations', p. 227, emphasis added.

${ }^{43} \mathrm{Pan}$, 'Toward a new relational ontology in global politics', p. 343, emphasis added.

${ }^{44}$ Agathangelou and Ling, 'The house of IR'.

${ }^{45}$ Ibid., p. 35 .

${ }^{46}$ Ibid., p. 36, emphasis added.

${ }^{47}$ Shilliam, The Black Pacific, p. 3.

${ }^{48}$ Kozuke Shimizu, in Trownsell et al., 'Differing about difference'.

${ }^{49}$ Ling, The Dao of World Politics.

${ }^{50}$ See also Qin, 'A relational theory of world politics'.

${ }^{51}$ Javier Medina, Ch'ulla y Yanantin: Las dos matrices de civilización que constituyen a Bolivia (La Paz: Garza Azul Impresores y Editores, 2008); Mazlish, Reflections on the Modern and the Global.
} 
relational understandings there is no 'West' or 'non-West' as self-contained units, just fractal or partial manifestations ${ }^{52}$ of Western or non-Western worldings resonating with each other. In the immanent West, the non-West is latent and the other way around, making it impossible for them to become something separate and different from each other. As Jarrad Reddekop puts it, relational interplay 'is perhaps not unlike the experience of viewing a Gestalt picture: once one has seen the duck, for example, one can never quite go back to seeing only the rabbit', ${ }^{53}$ and yet both the rabbit and the duck exist as such, but at the same time form part of the same image. Therefore, beings are and are not the same thing and at the same time, they juxtapose and intertwine. ${ }^{54}$

Trying to 'capture' these interaction acts against the nature of relational dynamics and is therefore not only impossible but also undesirable. As Kurki argues, this is challenging because '[b]eing, or becoming, situated in relations is difficult, as we do not quite know where we are, how we are made, and how to "relate to relations"; and yet in these relations it becomes difficult to ignore the many relations we rely on to process in the world. ${ }^{55}$ Consequently, Kurki recognises that the tendency to think in terms of 'things' is no longer a plausible starting point, ${ }^{56}$ at least not the only one if the purpose is to contribute to a more plural IR.

Relational approaches have made major contributions to the ways we understand global politics and our relationship with the world. ${ }^{57}$ Approaches to IR that draw from relational cosmologies are enriching because they are not about 'better' or 'new' ways of doing IR, but distinctive, disruptive, and alternative paths to doing IR differently, to recraft $i^{58}$ in ways that allow us to engage with difference differently, by highlighting the importance of cultivating varied ways of relating, coexisting, and collaborating. ${ }^{59}$ Yet, given the challenges faced even by relational ways of engaging relations developing relational thought and practice, as any other task, requires practice for better negotiating the difficult coexistence of different realities. ${ }^{60}$ The impossibility of defining should not become a lamentation. Shifting our concern to how relations relate instead of what relationality might help to overcome the trap. Here, I use the term cosmopraxis to illustrate how.

\section{Cosmopraxis}

Life is primarily about connection. ${ }^{61}$ Relationally speaking 'the movement of life is specifically of becoming rather than being, of the incipience of renewal along a path rather than the extensivity of displacement in space'. ${ }^{62}$ Becoming and transformation are fundamental features of how reality is shaped. Keeping in mind that relational ontologies are ontologies of transience, one can only fully understand how relations shape reality though practices. Bruno Latour, John Law, Law and

\footnotetext{
${ }^{52}$ Marilyn Strathern, Partial Connections (New York, NY: Altamira Press, 2004).

${ }^{53}$ Jarrad Reddekop, 'Thinking Across Worlds: Indigenous Thought, Relational Ontology, and the Politics of Nature' (PhD dissertation University of Western Ontario, London, Ontario, Canada, 2014), p. 53.

${ }^{54}$ Silvia Rivera Cusicanqui, Un mundo ch 'ixi es posible: Ensayos desde un presente en crisis (Buenos Aires: Tinta Limón, 2018).

${ }^{55} \mathrm{Kurki}$, International Relations in a Relational Universe, p. 135.

${ }^{56}$ Ibid., p. 5.

${ }^{57}$ Blaney and Tickner, 'Worlding, ontological politics'.

${ }^{58}$ Trownsell et al., 'Recrafting International Relations'; Blaney and Trownsell, 'Recrafting IR by worlding multiply'.

${ }^{59}$ Ling and Pinheiro, Dialogics in Multiple Worlds; Amiria J. M. Salmond, 'Transforming translations (part 2): Addressing ontological alterity', Journal of Ethnographic Theory, 4:1 (2014), pp. 155-87; June M. Rubis and Noah Theriault, 'Concealing protocols: Conservation, Indigenous survivance, and the dilemmas of visibility', Social and Cultural Geography (2019), pp. 1-23; Shilliam, The Black Pacific.

${ }^{60}$ Hutchings, Decolonizing Global Ethics.

${ }^{61}$ Wilhelm Dilthey, Teoría de la concepción del mundo (México-Buenos Aires: Fondo de Cultura Económico, 1954), p. 62.

${ }^{62}$ Tim Ingold, Being Alive: Essays on Movement, Knowledge and Description (London, UK and New York, NY: Routledge, 2011), p. 72 .
} 
Marianne Lien, Eduardo Viveiros de Castro, and Martin Holbraad ${ }^{63}$ among others, have illustrated how our practices constitute our realities. Hence, from a relational point of view, practices can be understood as worldings. Mario Blaser refers to worldings as worlds in the making through practices, ${ }^{64}$ thus underlining the idea that ontologies need to be enacted. ${ }^{65}$ For Ling, worldings are practices of marginalised groups to affect politics, ${ }^{66}$ and that such practices enact different worlds from those produced by European imperialism and settler colonialism. Blaney and Tickner outline that the notion of worlding has been used to refer to situated practices that make many worlds that place the conversation in other terms with the advantage of sidestepping the ontological problem of accepting the existence of a singular world. ${ }^{67}$

Worldings depend on cosmological assumptions. While atomistic ontologies enhance the world as a universe keeping other worlds latent, relational ontologies enhance reality as pluriversal. We live our lives according to whether we think of reality as a universe or as a pluriverse, and that determines also how our practices reproduce specific realities and could explain why the universe coexists with the pluriverse. It is through these practices that we enact our worlds, world our worlds, and therefore it is politically relevant to understand how. Putting it in simpler words: If one believes that cosmical matters are key to explaining and defining existence, one will accept other dimensions as part of reality; whereas if one believes that there is a differentiation between the human world and the rest as inanimate matter, then only human actions and human dimensions will be relevant to define reality. In the first case, social and political orders are constituted by humans and other-than-human worlds, and institutions, rules, laws, and other organisational aspect will reflect that. Accordingly, members of that society will practice pluriversal realities, such as using rituals to communicate with other beings, as multidimensional diplomacy. ${ }^{68}$ In doing so they are more aware and sensible to the ways to connect and communicate with those other dimensions and worlds that are interconnected to ours. They have developed the skills to do so. In the second case, practices will limit to human actions, orders, and rules since the great divide between nature and society establishes two different orders for each. Under this framework, our ways of being in and with the world are reflected in practices such as state building, sovereignty, migration, international organisations, and the international agenda in general, that leave the other-than-human, and the cosmical dimensions out of the equation.

It has been illustrated how through practices of colonisation a single world has been enacted, ${ }^{69}$ and that is also why relations relating that unfold a pluriverse are a meaningful tool of decolonisation. But it is also important to highlight that enacting worlds can have other manifestations too. For example, Kurki shows that not all conceptions of universe are antithetical to pluriverses, and many 'multiverse' theories in physics are also atomistic. ${ }^{70}$ In fact, relational worldings would

\footnotetext{
${ }^{63}$ Latour, 'Another way to compose the common world'; John Law, After Method: Mess in Social Science Research (London, UK: Routledge, 2004); Law, 'What's wrong with a one-world'; John Law and Marianne Lien, 'Denaturalising nature', in Marisol de la Cadena and Mario Blaser (eds), A World of Many Worlds (Durham, NC: Duke University Press, 2018); Eduardo Viveiros de Castro, 'Perspectivismo e multinaturalismo na América indígena', O o que nos faz pensar, 18 (2004), pp. 1-30; Martin Holbraad, 'The power of powder: Multiplicity and motion in the divinatory cosmology of Cuban Ifá (or mana, again)', in Amiria Henare, Martin Holbraad, and Sari Wastell (eds), Thinking Through Things: Theorising Artefacts Ethnographically (London, UK and New York, NY: Routledge, 2007), pp. 189-225.

${ }^{64}$ Mario Blaser, 'Ontology and indigeneity: On the political ontology of heterogeneous assemblages', Cultural Geographies, 1:10 (2012), pp. 49-58.

${ }^{65}$ Mario Blaser, in Marisol De la Cadena, Marianne Lien, Mario Blaser, Casper-Bruun Jensen, Tess Lea, and Atsuro Morita, 'Anthropology and STS: Generative interfaces, multiple locations', HAU: Journal of Ethnographic Theory, 5:1 (2015), pp. 437-75 (p. 453).

${ }^{66}$ Theriault et al., 'Living protocols', p. 7; Ling, The Dao of World Politics, p. 2.

${ }^{67}$ Blaney and Tickner, Worlding, Ontological Politics, p. 294.

${ }^{68}$ Tickner and Querejazu, 'Weaving worlds'.

${ }^{69}$ Mario Blaser, Storytelling Globalization from the Chaco and Beyond (Durham, NC: Duke University Press, 2013); Shilliam, The Black Pacific.

${ }^{70}$ Kurki, International Relations in a Relational Universe.
} 
by nature engage with universal realities as part of the interaction. As has been previously explained, immanence and latency are key to understand the relational interaction of contradictory forces. While atomistic worldings suppress other worlds they do not disappear, they are only latent. Relational worldings would enhance the presence of suppressed worlds to achieve a certain balance of opposite forces (yin/yang). How reality is worlded enacts an interrelated world where the universe is in interaction and intertwined with other worlds because all of them are immanent to each other.

Considering latency and immanence is an important way to understand change from a deep and ontological plurality that gives practices a very distinct meaning from that of what the 'practice turn' in IR has suggested. ${ }^{71}$ Hence, to differentiate the argument from that literature, I refer to practices as worldings, with the purpose of highlighting their pluriversal dimensions. As such relational practices connect cosmologies and other-than-human worlds, interacting. They bring back worlds and uses that have been outcast by mainstream approaches but that are particularly important and insightful for worlding relational worlds.

Cosmopraxis is a way of worlding. It refers to the experience of moving about multiple worlds as practiced by people (including eventually, other-than-humans) and entails relational practices of co-participation in the cosmos. ${ }^{72}$ The term has been used by Koen De Munter and Nicole Note and Denise Arnold ${ }^{73}$ to refer to worldings of the Aymara communities in the Andes who share a relational cosmology. But if the term responds to a specific origin the idea behind cosmopraxis is present in relational cosmologies known as as 'cosmic living/experience' (cosmovivencia or cosmoexperience), ${ }^{74}$ which according to Trownsell 'encompasses all possible ways of engaging in and interacting with existence. Ontologically it is more robust than "worldview" because of its cosmic scope, emphasis on the living and doing through a wider range of sensory channels. ${ }^{, 75}$ The difference between cosmopraxis and cosmoliving is that the former highlights practices, actions, and sensibilities ${ }^{76}$ that aim at connecting dimensions, which can take place as everyday actions by every being as illustrated in the next section. One of the most important dynamics in relational cosmologies is that everything is interrelated by dual and complementary forces that make up a 'corresponding world': how it is inside is outside, how it is up is down, how is the

\footnotetext{
${ }^{71}$ As a methodological move, one of the purposes of the 'practice turn' in IR is to bring theory down back to the ground of world politics (Emanuel Adler and Vinvent Pouliot 'International practices', International Theory, 3:1 (2011), pp. 1-36 (p. 6)) reducing the distance between policymakers or practitioners and the academy making a compelling criticism to theoretical abstractions. It also provides a theoretical intersection and inter-paradigmatic conversation of theoretical approaches. To authors of this turn, practices are competent performances to transcend the 'levels of analysis' that affect a material world that is 'out there' and focuses on what practitioners do. See Adler and Poiliot, in Patrick Thaddeus Jackson, Emanuel Adler, Vinvent Pouliot, Rebeca Adler-Nissen, Ole J. Sending, Ole Jacob, Christian Bueger, and Frank Gadinger (eds), The Practice Turn in International Relations (DeRaismes Combes, 2017), or as Alder-Nissen suggest a bundle of theories that can explain world politics (ibid.); or a diverse family, distinctive set of theoretical tools to understand the social world that make of practice theory a melting pot (Bueger and Gandiger, in Jackson et al., The Practice Turn, p. 9.

${ }^{72}$ Koen De Munter and Nicole Note, 'Cosmopraxis and contextualising among the contemporary Aymara', in Nicole Note, Raul Fornet-Betancout, Josef Esterman, and Aerts Dietrik (eds), Worldviews and Cultures: Philosophical Reflections Form an Intercultural Perspective (New York, NY: Springer, 2009).

${ }^{73}$ De Munter and Note, 'Cosmopraxis and contextualising'; Denise Y. Arnold, 'Hacia una Antropología de la Vida en los Andes', in Denise Arnold, ltxaso Arias, Víctor H. Castro, Angel R. Dollinger, A. Palmenia Frías, Wendy Gutierrez, Rosmery Villca, Guido Montaño, Amanda Ajata, and Alvaro Huanca, El Desarrollo y lo Sagrado en los Andes: Resignificaciones, interpretaciones y poropuestas en la cosmo-praxis (La Paz: ISEAT PIEB, 2017).

${ }^{74}$ Simon Yampara, 'Cosmovivencia Andina: Vivir y convivir en armonía', Bolivian Studies Journal, 18 (2011), pp. 1-22; Leonardo Figueroa, 'Indigenous Philosophy and World Politics: Cosmopolitical Contributions from across the Americas' (PhD dissertation, Arizona State University, Tempe, Arizona, 2012). See also Vince Deloria Jr, God Is Red (Golden, CO: Fulcrum Publishing, 2003); Enrique Cachiguango, 'Así nomas compartimos nuestras prácticas, saberes, sentires y conocimientos' (Ministry of Education, Plurinational State of Bolivia, 2019), available at: \{https://www.facebook.com/minedubol/ videos/1366758240145214/\} accessed 30 April 2021

${ }^{75}$ Tamara Trownsell, 'Recrafting ontology', forthcoming.

${ }^{76}$ Tickner and Querejazu, 'Weaving worlds'.
} 
past is the future because it is a cyclical world. What exists is and is not the same at the same time, like a Gestalt image. This correspondence and complementation of 'opposites' creates extensive links with the other-than-human co-participation of other worlds (natural, divine, ancestral). ${ }^{77}$ For example, a photograph can be used in a long-distance healing because it corresponds to the reality one intends to affect. ${ }^{78}$ In this corresponding dual world faculties are also complementary: reason and intuition balance and complement each other, and together they constitute our cosmic awareness. This correspondences are also evident in Daoist yin/yang, Mayan 'tojolabal 'ab 'al $y$ k'umal' ('I speak you listen') ${ }^{79}$ or in the Ubuntu expression 'I am we; I am because we are; we are because I am ${ }^{\prime 80}$ and reveal - as I illustrate in the following sections -, how cosmopraxis is both a situated and contextual (local) experience and the effect of relations relating and echoing throughout the world. Accordingly, wisdom, knowledge, facts, and truths are not 'out there' but correspondingly within us, and they do not occur in isolation. Every process of knowing and being is necessarily a collective process involving human and other-than-human participation, a cosmic practice, and is not an abstraction but an experience.

As a way of worlding, cosmopraxis is the result of the interconnection of situated practices that create and transform reality while engaging simultaneously the experience of doing/knowing/ being. The experiences of being, knowing and doing, are more than ontology, epistemology, and methodology, not only because they are interconnected but because they concur as unfolding relations: doing while feeling while knowing while being. ${ }^{81}$ As relational experiences they happen together, such simultaneity is bodily experienced and becomes a way of going about the world as everyday life. As I have illustrated in the first section, sometimes dominant, languages are limiting. Performative worldings and embodiments become other forms of expression that we must take into consideration because some experiences cannot be fully expressed with specific (academic) languages, nor are limited to discursive practices. ${ }^{82}$ For example, even if we think that a learning process is cognitive or rational more than emotional, emotions are latent, therefore cosmopraxis balances that latency and enhances the emotional part of knowing while keeping the rational experience as well and both together impact the being, conforming a whole or holistic experience of knowing/feeling/being, but that experience does not occur in abstraction, but in action (doing). Cosmopraxis involves the relational practices of co-participation, it gives more importance to concrete acts of commemoration that create relations (like sharing food) than to the cognitive abilities of categorising, distinguishing, and controlling, ${ }^{83}$ which create concepts, highlighting the importance of everyday life 'relational ways of doing' and how they can be cultivated or practiced to develop the sensibilities to become more aware and versatile in moving and connecting with other worlds.

Cosmopraxis is practical, experiential, and ritual. The practical dimension enhances skillful learning, collective participation, and the ability of knowing while doing. The emphasis on the practical is key because wisdom comes from lived experience. But practical wisdom and experience need cultivation and guidance, they need to be learned and repeated. The experiential dimension highlights the pluriversal context because it stresses skills of learning how to listen

\footnotetext{
${ }^{77}$ See examples in Watts, 'Indigenous place-thought \& agency'; Kim Tallbear, 'Being in relation', in Samantha King, R. Scott Carey, Isabel Macquarrie, Victoria N. Millious, and Elaine M. Power (eds), Messy Eating: Conversations on Animals as Food Being in Relation (New York, NY: Fordham University Press, 2019); Deloria Jr, God Is Red.

${ }^{78}$ Cachiguango, 'Asi nomas compartimos'.

${ }^{79}$ Figueroa, 'Indigenous Philosophy and World Politics'.

${ }^{80}$ Bagele Chilisa, Indigenous Research Methodologies (London, UK and New York, NY: Sage Publications Inc., 2012), p. 109.

${ }^{81}$ Tickner and Querejazu, 'Weaving worlds'.

${ }^{82}$ Critical scholars from ethnographic/anthropological, feminism turns direct greater attention to non-discursive practices and embodied actions. See Omura et al., The World Multiple; Blaser, Storytelling Globalization; Ruth Thomas-Pellicer and Vito De Lucia, 'Introduction: Exploring re-embodiments', in Ruth Thomas-Pellicer, Vito De Lucia, and Sian Sullivan (eds), Contributions to Law, Philosophy and Ecology (New York, NY: Routledge, 2016).

${ }^{83}$ Thomas-Pellicer and De Lucia, 'Introduction', p. 16.
} 
and to read signs that surround us, moment by moment, which go beyond our human activity. ${ }^{84}$ The survival of every species in the world depends on the capacity to understand its surroundings and adapt. Cosmopraxis results from knowledge of adapting and conversing with the environment transmitted (mostly orally) from generation to generation. It carries the know-how of the ancestors, but it is also nourished through situated and concrete experiences. The need to find balance between those actions has been the primary reason to make sense of the cosmos and to learn how to survive, listen and learn from context (beings, times, spaces). ${ }^{85}$ The ritual dimension implies skills of respectful repetition, imitation (of human and other-than-human practices), careful and attentive order and proceedings with the awareness and responsibility of actions repercussions through acts of reciprocity. ${ }^{86}$ It is by ritualising the experience that awareness emerges and differentiates itself from a routine action or unconscious experience. For example, a simple action like sharing food acquires a whole new meaning when it is ritualised, participants are more aware of the implications of the relations relating, and how it involves not only the human community but also the other-than-human that take part of the ritual (food, music). The creative activity of weaving connects with the cosmos, it creates a link between the sheep from where the wool comes and the weaver, a link between weavers and their ancestors who passed to them the know-how to weave. Once finished a weaving becomes the symbol of those interconnections. ${ }^{87}$

\section{Relational ways of cosmopraxis}

Cosmopraxis entangles and combines everyday life ways of doing things. The word way is specifically relevant not only because it refers to 'methods', means, and forms of knowing, but because it also refers to paths that can be followed and that lead and connect to other worlds. These ways can be expressed in playful language and expressions that highlight actions in relation: 'You know what you are doing, where you are going ${ }^{88}$ and while you are doing it like other actions of life like 'walking and standing with', 89 'asking we walk', 90 'learning by doing as being, ${ }^{91}$ and doing things until we learn to make them right again. ${ }^{92}$ Different relational languages are also important like the use of oral language - which is preferred - proverbs, metaphors that reveal recipes to practices of 'experiencing, transmitting and interchanging their way of going about the world in a dynamic way of everyday, ritual and celebratory acting, and less on conceptually grasping it'. ${ }^{93}$

Singing, dancing, ${ }^{94}$ storytelling, ${ }^{95}$ dreaming, ${ }^{96}$ weaving, ${ }^{97}$ metaphors, proverbs, and myths ${ }^{98}$ and every other creative craft can become a 'relational way' of aware acts of connecting. As

\footnotetext{
${ }^{84}$ Figueroa, 'Indigenous Philosophy and World Politics'; Deloria Jr, God Is Red; Cachiguango, 'Asi nomas compartimos'.

${ }^{85}$ See Hans Van den Berg, “'La tierra no da así nomás”', Ciencia y Cultura, 15 (2005), pp. 1-331.

${ }^{86}$ Cachiguango, 'Asi nomas compartimos'; Bawaka Country et al., 'Bunbum ga dhä-yutagum'.

${ }^{87}$ Tickner and Querejazu, 'Weaving worlds'.

${ }^{88}$ Bawaka Country et al., 'Bunbum ga dhä-yutagum', p. 11.

${ }^{89} \mathrm{Kim}$ Tallbear, 'Standing with and speaking as faith: A feminist-Indigenous approach to inquiry (Research note)', Journal of Research Practice, 10:2 (2014), pp. 1-8.

${ }^{90}$ Zapatista principle, which highlights not only the idea that we only know as we walk but also the relevance of place. Sixth Declaration of the Selva Lacandona, available at: \{http://enlacezapatista.ezln.org.mx/2005/06/30/sixth-declaration-of-theselva-lacandona/\} accessed 22 May 2020.

${ }^{91}$ Cachiguango, 'Asi nomas compartimos'.

${ }^{92}$ Bawaka Country et al., 'Bunbum ga dhä-yutagum'.

${ }^{93}$ De Munter and Note, 'Cosmopraxis and contextualising', p. 89.

${ }^{94}$ Bawaka Country et al., 'Bunbum ga dhä-yutagum'; Helen Verran, 'A postcolonial moment in science studies: Alternative firing regimes of environmental scientists and Aboriginal landowners', Social Studies of Science, 32:5 (2002), pp. 729-62.

${ }^{95}$ Blaser, Storytelling Globalization.

${ }^{96}$ Tim Ingold, 'Dreaming of dragons: On the imagination of real life', Journal of the Royal Anthropological Institute, 4:19 (2013), pp. 734-52; Deloria Jr, God Is Red.

${ }^{97}$ Tickner and Querejazu, 'Weaving worlds'.

${ }^{98}$ Deloria Jr, God Is Red; Chilisa, Indigenous Research Methodologies.
} 
such, they channel relations, transmit and preserve messages and knowledge for 'future' generations, and connect to other worlds. Every song, dance, dream, or story becomes itself a vivid relation that is also and at the same time the intangible repository of the messages, wisdom, or knowledge that is to be preserved and communicated to others. When we sing/dance/dream/ tell stories, we co-become with the stories, dances, dreams, and that connects us with different times, and with different beings. Each one of these ways as 'methods', when enacted, has the capacity to connect times, they bring back experiences while also transporting us to other times, dimensions, and spaces (intangible, oneiric, magic); they connect us in conversation with other-than-human beings (ancestors, spirits, animal, plants). And most importantly, another characteristic of these ways of doing is that they are inherent to all beings and part of our daily lives. As practices that have been outcasted from academic and scientific realm it is hard to see how they could be relevant to contribute to a field like IR and can be easily dismissed as proper 'methods'. 'What do magic, dreams, songs, storytelling have to do with world politics'? Acknowledging and remembering that they were already part of world politics before we came with the term 'world politics' is important. Perhaps we should ask the question differently: why not use all the skills we have at our disposal to expand the ways we can come up with meaningful answers and sensemaking of the complex realities we live? As already argued, it is not about better methods, but different; it is about multiplying the means at our disposal. For many researchers, rituals, dreams, songs, and other relational ways might be more insightful and significative than a statistical regression.

By being aware of their role as ways of cosmopraxis (both as 'methods' and as paths), we develop a sense of shared and social connection and a sense of belonging, and we get a better sense of how relations relate. With awareness and the use of rituals and practice their role as 'normal', 'human' activities change into a cosmopraxis, a situated worlding that impacts our ways about the world 'somehow' else. Consider for example two acts of connection: dreams and songs. We can be experts in oneiric symbols, or in the subconscious, or we can be experts in music, but such expertise does not really prepare us to navigate a dream or to listen to a soon for the first time. In both cases we can have some idea of what is going on, but we only know how to act/react during the experience and while it affects us and our realities. Cosmopraxis demands of us to be aware and more intuitive, to navigate them and in so doing it changes relation to the knowledges we think we have.

Before analysing an example, some guiding questions are useful to grasp the workings of cosmopraxis: What connections does the story/song/dream/weaving establish? What knowledges does it preserve? What message does it contain? What is their temporal relevance (timelessness)? How is it practiced (rituals, ceremonies, academic exercise, everyday action)? What other worlds or beings take part take or are involved? How do they affect the experience of those involved?

If all that has been argued here seems strange or unfamiliar to an IR reader, the following example illustrates the argument and shows cosmopraxis as an academic exercise for IR. In Sihar \& Shenya, A Fable for Our Times, Ling ${ }^{99}$ explains Daoist interaction of yin/yang using the relational method of storytelling. As the reader goes through the story the relation between the feminine (the priestess) and masculine (the king), human and other-than-human, past, present, and timelessness become apparent and so do the particular problems such as power, sovereignty, migration, to mention some, which belong to a traditional research and study agenda of IR. Storytelling is the 'method' and the fable told is the repository of messages and knowledge. But the fable is not just a story; it is told in a way that illustrates how relations relating can transform the reality not only of the story itself, but also of the reader. In the second part of the book variables like love, security, wealth, power, knowledge are narrated as beings, actors with political will, balanced with their latent correspondent force and linked with one of the five elements in Daoist cosmology: Knowledge-water, Love-air, Power-fire, Wealth-metal, Security-earth. In the

${ }^{99}$ L. H. M. Ling, Imagining World Politics: Sihar \& Shenya, A Fable for Our Times (New York, NY: Routledge, 2014). 
story, instead of inert variables used by humans to produce knowledge, the five elements become the five mythic ones who use the human world as the laboratory to discover what combination between them makes for happiness in the world. Every combination leads to a competing result of forces. The conclusion is that instead of competing, the five forces can create a balance, as the story of Sihar and Shenya exemplifies. Ling tells a story about balance of forces and a different imagination of world politics where 'they are all related! Power, Wealth, Love, Security, Knowledge. Each one needs the others not just to make sense of the Universe but, also, simply to be. ${ }^{, 100}$ Ling brings in the latent forces (love, other-than-human, spiritual) and the result is a very different narrative of world politics.

Ling worlds a cosmos (cosmopraxis), using mainly storytelling as the way to connect. Ling does not come with the story on her own, but she is retelling the story as she knows it and adding some elements of her own creation or interpretation. What this way does for IR is that it enhances the latent, silenced forces, energies, and worlds, and its purpose is to bring back balance to an IR that 'is all yang and no yin'. ${ }^{101}$ In the story the yang is represented by the king and the yin by the priestess, the feminine dimension that brings wisdom to the king's decisions. The priestess wisdom comes from knowing the revelations of nature. Trees, seeds, natural beings reveal messages to her, and it is with her advice that kings can find solutions to conflict and tensions. In the story these aspects are not treated as categories 'war', 'conflict', 'migration'. The result is a collective and social story that involves the participation of many. The story contains elements of traditional IR with the difference that the story worlds a relational IR reality. The reader can tell them though without a concrete reference to them as IR categories.

As opposed to the previous critique about dialectics, here Ling uses a relational method to illustrate a relational narrative of world politics. The fable enacts a pluriversal way of addressing global political issues. This is a story about politics that involves other worlds. As cosmopraxis it brings back the outcast: magic, dreams, beliefs, and myths and enacts an enchanted pluriversal yet analytically strong IR scenario. Most important, as a cosmopraxis it does not only change IR reality for Ling, but for the reader, because it shows another 'how' to IR. Ling's invitation to imagine world politics helps to understand cosmopraxis as worlding, because if the reader can imagine it, what normally would be considered irrelevant to IR, becomes possible and can eventually be practiced as IR. If one reads this fable guided by the questions stated before it is evident how cosmopraxis works and how it contributes towards thinking of a pluriversal IR.

As Haraway affirms, as scholars we can do fabulations and that does not mean we are not telling truths. ${ }^{102}$ But sometimes we need richer, more imaginative, creative, ${ }^{103}$ science/fictional forms of expressions and of doing IR. With the use of everyday actions of connecting such as dreaming, dancing, singing, cosmopraxis prepares us to enchant and be re-enchanted. By re-enchanting I do not refer to religious endeavours, ${ }^{104}$ but to the mind and heart disposition to be amazed and surprised by the possibilities life offers. As Graham Harvey argues, 're-enchanting should be about moving beyond the duality "you believe/we know", and that some knowledges only are acquired through "leaps of faith"' ${ }^{105}$ To re-enchant the world is to think and face life as a child, to learn and listen without preventions, open to other possibilities or likelihoods, to allow the potential of our imagination to inform the way we address global issues and concerns. Not filtered by the

\footnotetext{
${ }^{100}$ Ibid., p. 181.

${ }^{101}$ Ibid., p. xxii.

${ }^{102}$ Donna Haraway, in Fabrizio Terranova, Donna Haraway: Story Telling for Earthly Survival, documentary (Brussels, 2016).

${ }^{103}$ Roland Bleiker, Aesthetics and World Politics (New York, NY: Palgrave Macmillan, 2009).

${ }^{104}$ For the implications of assuming enchantment, beliefs, sacred, and spiritual as dimensions of religion and opposed to the secular, see Bruno Latour, On the Modern Cult of Factish Gods (Durham, NC: Duke University Press, 2010); Trownsell, 'Recrafting ontology'.

${ }^{105}$ Graham Harvey, Food, Sex and Strangers: Understanding Religion as Everyday Life (New York, NY: Routledge, 2013), p. 148.
} 
hyper rationalisation of the adult and acknowledge that we need other sensibilities, intuitions, and imaginations to learn how to navigate the cosmos that has only superficially revealed to us.

\section{Cosmopraxis for a pluriversal IR}

The potential of cosmopraxis for how we can craft, and world IR differently is evident and needs to be further explored. This text shows at least four contributions: first, cosmopraxis is about practices that anyone can experience and that relate to the cosmos. It contributes to relational approaches that offer both/and logics. Cosmopraxis refers to acts of connecting that every being can experience and practice, it becomes a relational tool to analyse both concrete situated - in place/time - standpoint experiences and the possibility to see how interconnected we are in our similarities and resonances without the need to advocate for totalising terms such as 'universal', 'global', or 'common'. In the previous section, I mention some of those practices as ways of connecting with other worlds and to access to knowledge about those worlds we are part of. Cosmopraxis is about cultivating and becoming familiar with those ways of relating and revalidate them to nurture IR differently. Such ways of enacting the world are not only meaningful and politically significative for many people but also necessary to see that the abilities and skills we need to better understand relational worlds are inherent to all beings. In displaying these ways of doing as more than mundane practices of live and revealing their pluriversal dimensions as connectors, these 'methods' enrich, re-enchant, and enable not only silenced worlds but academically discredited practices that are meaningful sources of knowledge about the worlds we inhabit. Cosmopraxis displaces us from our usual - detached - forms to approach global politics while at the same time puts us in places that are familiar to us because they are part of our daily lives. Other languages and forms of expressions, other ways of knowing and of being colour the traditional IR lexicon.

Second, cosmopraxis illustrates how relational methods can cultivate relevant knowledge for IR, not only as means of decolonising methodologies but also to build a pluriversal IR. It is not about indigenous experiences or indigenous worldings 'out there' 'far away' that 'we know nothing about'. It is about relearning how to relate by bringing those connectors back into our lives as being politically relevant, particularly to global politics. Therefore, while some people are born and embedded into relational cosmologies, and have practiced relations and become skilled relating, others have still to develop awareness. Perhaps political communities (whether indigenous, migrants, Western, and the like) are just in different stages of awareness. But that is a relation that can be transformed, because it depends on how we world reality. How to relate is something that all of us knew but some have forgotten through a series of historical processes. Relating is also remembering. Focusing on how relations relate restores our cosmic memory. Being innate skills, with practice and awareness, they connect us with the cosmos not as specific groups but as participants, as part of relations.

Third, cosmopraxis provides an alternative to bypass the problem of reifying relationality and fixing the meaning of relations. By nature, relations cannot be reduced to and be intelligible as having an 'essence'. Yet to see how they work we need to understand ontology as being radically different. While familiar with the ontology of presence that seeks to capture the being, we need to become familiar with ontologies of transience where all is passing, living, becoming, and in a ceaseless cyclical transformation, ${ }^{106}$ and deeply engage in practices of relating and understand deep relations from within and along. This means focusing on the how and developing (practice) the skills and ability to relate and to bring back - rebind - that which has been rent asunder. ${ }^{107}$ The logic of transience discussed here illustrates this. Acknowledging that existence is in constant transformation contests languages that seek to fix meaning and categorise existence. But it is also challenging to offer alternatives that produce robust understandings and insights too. Focusing on

\footnotetext{
${ }^{106}$ Figueroa, 'Indigenous Philosophy and World Politics', p. 44.

${ }^{107}$ Shilliam, The Black Pacific, p. 16.
} 
how reality is shaped through worldings that imply simultaneous processes of knowing, doing, and feeling (cosmopraxis) makes for concrete and situated experiences that are at the same time cosmically embedded. Our existence is defined by our path in the world, therefore the ways that we transit the path are more revealing than what that existence might be. Cosmopraxis gathers information about the path while we transit.

Finally, cosmopraxis illustrates other forms of dealing with the coexistence of difference, ${ }^{108}$ not only of different worlds but performatively exemplifies our own coexistence with different times and spaces, with different beings daily. Cosmopraxis allows us to combine other ways through which coexistence and the problem of ontological difference has been analysed, like Anne Salmond's dynamic processes of co-becoming 'ontological styles', ${ }^{109}$ or Richard Howitt and Sandra Suchet-Pearson's practice of 'situated engagement. ${ }^{110}$ If there can be a relational coexistence of methods and experiences (relational methods as repositories, connectors, messages at the same time), political and ontological coexistence among humans, other-than-humans and all their worlds can also be addressed in terms of entanglements and co-becomings. The idea of cosmopraxis enhances the latent. This means that what appears to be a simple action, a routine, reveals other dimensions as relations relating. The awareness of the existence of that latency what we usually do not see or feel or know - and bringing it into being makes it a transformative force that builds balance. Bringing back the latent, the silenced, bringing back difference, is a way of achieving balance. In sum, cosmopraxis can be used as a multidimensional pluriversal, relational map that tracks our path in this world, because a life experience (living) is related to making worlds (being) where all beings (human and other-than-human) are participants. Recognising this sets the ground for a different attitude to negotiate ontological difference. In that aspect, pluriversalising IR can mean worlding a more robust field better equipped to engage with ontological difference.

The political importance of all this be illustrated with Shilliam's poem 'Telling Stories':

Some stories are unknown. Some stories cannot be told. Some stories have yet to be told. Some stories are crying out to be told. Some stories have already been told but no one listened. When the time is right you will remember having been told some stories. You will pass some stories on, and you had better be careful. ${ }^{111}$

\section{Conclusions}

By approaching 'relationality' by how relations relate, this article has argued that focusing on relations as worldings is a way to understand and describe relations relating without conceptualising or reifying them. I also illustrate that, as beings, we all have what it takes to relate: some of us might have engaged more deeply in relations with difference, like other-than-humans, but all of us have it in us, as a result of relations that we are.

Relational experiences, and ways of worlding will always refer to something more. Focusing on relations gives us a sense that things are neither complete nor given, but rather, in a constant process of becoming. From an analytical point of view, cosmopraxis reveals that intertwined experience of the ontological, the epistemological and methodological as juxtaposed moments that together - as relations relating - condition our concrete experiences in and with the world. In

\footnotetext{
${ }^{108}$ Anne Salmond, 'Ontological quarrels: Indigeneity, exclusion and citizenship in a relational world', Anthropological Theory, 12:2 (2012), pp. 115-41.

${ }^{109}$ Ibid.

${ }^{110}$ As situated and experienced, 'situated engagements is introduced as an approach which encourages noisy and unruly engagement in situated, interacting material discursive and conceptual places ... This avoids reinforcing and recentering practices and concepts within the constraints of the hall of mirrors, within the globalizing essentialism of the colonial and postcolonial narrative.' Howitt and Suchet-Pearson, 'Ontological pluralism', p. 566.

${ }^{111}$ Robbie Shiliam, 'Telling Stories', Poetryprose, available at: $\{$ https://robbieshilliam.wordpress.com/about/\}.
} 
that sense they are always both situated and context dependent and at the same time account for the cosmos we inhabit.

This togetherness, juxtaposed, simultaneous interplay of relations is never melted into a single isolated experience, will always be a part of a previous experience and the beginning of a new becoming. As such, it cannot be singled out and analysed in isolation. Cosmopraxis contributes to the discussion about how worldings as situated practices constitute realities relevant to think IR differently, it illustrates how relations relate instead of what relationality is and informs about how to reflect on the coexistence of difference. It also contributes to think of situated specific experiences of knowing/being/doing both as situated but also inherent to all beings. Cosmopraxis is not a complex notion, it refers to the simplest actions of consciously connecting with the cosmos.

The need to conceptualie relationality responds to the way through which specific ontologies/ epistemologies/methodologies have been privileged to approach and understand the world. But also, every concept, every separation, every claim of universal truth is being disturbed by strong evidence of the interconnections that binds everything and that places limits and certainties in serious doubt. In a context in which the need of more plural and alternative ways of thinking about the global is becoming evident, instead of escaping our ghosts, let us converse and listen to them to remind ourselves that by 're-enchanting the world'. We bring back other worlds, thus paving the way to a more meaningful and pluriversal IR. This is an initial provocation, there is much more to be explored.

Acknowledgements. This research is part of the project 'Making Kin with Other Worlds. Relationality as Methodology to Build Pluriversal International Relations' (NIFBA19\190793), financed by the British Academy Newton Fund, as part of my Newton International Fellowship at Aberystwyth University. I would like to thank Navnita C. Behera, Milja Kurki, Giorgio Shani, Arlene B. Tickner, and Tamara Trownsell for their comments and advice. The journal editors and the three anonymous reviewers of the manuscript provided highly appreciated, detailed, and constructive feedback, for which I am sincerely grateful.

Amaya Querejazu is Associate Professor at the University of Antioquia and Newton International Fellow at Aberystwyth University.

Cite this article: Querejazu, A. 2022. Cosmopraxis: Relational methods for a pluriversal IR. Review of International Studies 48, 875-890. https://doi.org/10.1017/S0260210521000450 